\title{
Development of a serum-free medium for in vitro expansion of human cytotoxic T lymphocytes using a statistical design
}

\author{
Min Kyoung Jeon ${ }^{1}$, Jong-Baeck Lim², Gyun Min Lee
}

\begin{abstract}
Background: Serum-containing medium (SCM), which has a number of poorly defined components with varying concentrations, hampers standardization of lymphocyte cultures. In order to develop a serum-free medium (SFM) for the expansion of human lymphocytes from peripheral blood mononuclear cells (PBMCs), a statistical optimization approach based on a fractional factorial method and a response surface method was adopted. A basal medium was prepared by supplementing RPMI1640 medium with insulin, albumin, ferric citrate, ethanolamine, fatty acids, glutamine, sodium pyruvate, 2-mercaptoethanol, 1-thioglycerol, nonessential amino acids, and vitamins. We identified additional positive determinants and their optimal concentrations for cell growth through a statistical analysis.

Results: From a statistical analysis using the fractional factorial method, cholesterol and polyamine supplement were identified as positive determinants for cell growth. Their optimal concentrations were determined by the response surface method. The maximum viable cell concentration in the developed SFM was enhanced by more than 1.5-fold when compared to that in RPMI1640 supplemented with 10\% fetal bovine serum (FBS). Furthermore, a cytotoxicity assay and an enzyme-linked immunospot assay revealed that the effector function of cytotoxic T lymphocytes generated from PBMCs grown in SFM, by stimulation of peptide-presenting dendritic cells, was retained or even better than that in SCM.

Conclusions: The use of a developed SFM with cholesterol and polyamine supplement for human lymphocyte culture resulted in better growth without loss of cellular function when compared to SCM.
\end{abstract}

\section{Background}

Adoptive cell therapy using cytotoxic T lymphocytes (CTLs) has emerged as a new approach to treat patients with various types of cancers and viral infections, and its effectiveness has been demonstrated in Phase I/II studies [1-3]. CTLs play an important role in controlling viral infection and eliminating cells with malignant potential. In clinical trials involving the adoptive transfer of antigen-specific CTLs, CTL doses of $10^{7}-10^{9}$ cells per kilogram of body mass are required to achieve efficacy $[4,5]$. Thus, there has been considerable interest in developing an in vitro system to expand human CTLs

\footnotetext{
* Correspondence: gyunminlee@kaist.ac.kr

'Department of Biological Sciences and Graduate School of Nanoscience \& Technology (WCU), KAIST, 335 Gwahangno, Yuseong-gu, Daejon, 305-701, Korea

Full list of author information is available at the end of the article
}

for use in the implementation of adoptive immune therapies.

In general, the culture medium for in vitro expansion of CTLs is supplemented with serum, usually of human or fetal calf origin [6-8]. The serum supplement, however, significantly affects experimental results, because a large number of poorly defined components including growth factors, antibodies, and other immunologically active substances vary in concentration between batches [8]. Accordingly, a serum-free medium (SFM) needs to be developed for standardization of in vitro expansion of CTLs. However, despite the importance of SFM, its development for in vitro expansion of CTLs has not been fully substantiated.

Based on the findings of previous studies of SFM for human lymphocytes [8-10], we prepared a basal SFM for human CTLs through several culture experiments. 
To achieve better cell growth, growth-enhancing candidates lacking basal SFM for CTLs were identified by a literature search. Cholesterol, phospholipids, and polyamines, which are principal components in serum, were selected on the basis of their positive roles in cell growth of many mammalian cell lines [11-13]. Antioxidants, which are known to exert a synergistic effect on cell growth with polyamines [14], were also included as candidates. In order to assess the effects of these candidate components on the growth of CTLs, a fractional factorial design was employed to screen active factors for cell growth, followed by response surface designs to optimize their concentration.

The cellular functions of CTLs grown in the newly developed SFM were also characterized by a cytotoxicity assay and an enzyme-linked immunospot (ELISpot) assay. To generate antigen-specific CTLs, we used cytomegalovirus (CMV) peptide epitope NLVPMVATV as an antigen. Derived from the immunodominant CMV matrix protein $\mathrm{pp} 65$, it is one of the most widely studied antigens in clinical studies [15-17].

\section{Results}

\section{SFM designed by a fractional factorial method}

The basal SFM for in vitro expansion of T lymphocytes, the components of which are listed in Table 1, was formulated through a literature search and confirmed via culture experiments (data not shown). In order to further improve the SFM, 4 supplements, phosphatidylcholine, polyamine supplement, antioxidant supplement, and cholesterol, were selected as potential growth enhancers, based on their growth promoting abilities reported in previous studies with other cells. Due to a limited cell number, a statistical approach based on a fractional factorial design was applied for efficient testing of selected active supplements. As shown in the

Table 1 Composition of the basal SFM

\begin{tabular}{lr}
\hline RPMI1640 supplemented with: & \\
\hline Components & Concentration (/l) \\
\hline Bovine serum albumin & $2.5 \mathrm{~g}$ \\
Insulin & $5 \mathrm{mg}$ \\
Ferric citrate & $2 \mathrm{mg}$ \\
Ethanolamine & $1.22 \mathrm{mg}$ \\
Linoleic acid & $1 \mathrm{mg}$ \\
Oleic acid & $1 \mathrm{mg}$ \\
Palmitic acid & $1 \mathrm{mg}$ \\
L-glutamine & $584 \mathrm{mg}$ \\
Sodium pyruvate & $110 \mathrm{mg}$ \\
2-mercaptoethanol & $0.78 \mathrm{mg}$ \\
1-thioglycerol & $5.41 \mathrm{mg}$ \\
RPMl1640 nonessential amino acids & $20 \mathrm{ml}$ \\
RPMl1640 vitamins solution & $10 \mathrm{ml}$ \\
\hline
\end{tabular}

matrix presented in Table 2, kinds 8 of SFM were prepared. The first row of (-) elements in Table 2 is a basic assembly referring to the basal SFM. Since the culture performance of PBMCs in these SFM may depend on the donors, three sets of experiments were carried out independently with PBMCs prepared from three different donors. Cell cultures were performed with IL-2 supplementation, as described in the Materials and Methods section.

Figure 1 shows the growth profiles of PBMCs from one donor (Set \#1 in Table 3) in these media with IL-2 supplementation during cultures. Cells cultured in even numbers of SFM (\#2, \#4,\#6, and \#8), which are denoted with opened symbols in Figure 1, did not grow well. They maintained their initial seeding density or died gradually. Because the common supplement in the even numbers of SFM was phosphatidylcholine, it is likely that phosphatidylcholine inhibits cell growth. Maximum viable cell concentrations achieved in SFM $\# 3$, \#5, and \#7 were comparable to or higher than that in the basal SFM (SFM \#1). Although the growth patterns of PBMCs in the SFM depended on the donors, the general tendency regarding the effect of each supplement on growth did not change significantly (data not shown). The maximum viable cell concentrations achieved in the cultures of PBMCs from the three different donors with the SFM are summarized in Table 3.

To determine positive factors for cell growth from among the 4 supplements tested, the maximum viable cell concentrations in each culture were evaluated in the normal probability plot.

Figure 2 shows the normal probability plot of the fractional factorial design. In the normal plots, the ordered effects are plotted on the $\mathrm{x}$-axis, and the appropriate normal \% probability is plotted on the y-axis. If some of the variables affect the response, real effects will fall off the line in the plot, either high and to the right (for positive effects) or low and to the left (for negative effects) [18].

The main effect of phosphatidylcholine, located in the lower left-hand portion of the plot, was always negative with regard to cell growth, consistent with the previous assumption. Cholesterol, located in the upper right-hand of the plot, always showed a positive effect on cell growth. In the case of the polyamine supplement, a positive effect was shown in two out of the three tests. As for the antioxidant supplement, a negative effect was observed in two out of the three tests. Accordingly, among the four candidates, excluding the clearly negative candidate (phosphatidylcholine) and one possibly negative candidate (antioxidant supplement), cholesterol and polyamine supplement were chosen as active factors on cell growth. 
Table 2 Matrix of the fractional factorial design $\left(2^{4-1}\right)$ for the 4 supplements

\begin{tabular}{|c|c|c|c|c|}
\hline \multirow{3}{*}{ SFM } & \multicolumn{4}{|c|}{ Basal SFM supplemented with: } \\
\hline & A & B & C & $D=A B C$ \\
\hline & $\begin{array}{l}\text { Phosphatidyl } \\
\text { choline } \\
\text { (5 mg/l) }\end{array}$ & $\begin{array}{c}\text { Polyamine } \\
\text { supplement } \\
(1 \times)\end{array}$ & $\begin{array}{c}\text { Antioxidant } \\
\text { supplement } \\
(1 \times)\end{array}$ & $\begin{array}{c}\text { Cholesterol } \\
(4 \mathrm{mg} / \mathrm{l})\end{array}$ \\
\hline$\# 1$ & - & - & - & - \\
\hline$\# 2$ & + & - & - & + \\
\hline \#3 & - & + & - & + \\
\hline \#4 & + & + & - & - \\
\hline$\# 5$ & - & - & + & + \\
\hline$\# 6$ & + & - & + & - \\
\hline \#7 & - & + & + & - \\
\hline \#8 & + & + & + & + \\
\hline
\end{tabular}

$(-)$ no addition; (+) addition of the indicated amount of additives.

\section{Determination of optimal concentrations of supplements} using a statistical analysis

In order to optimize the concentration of cholesterol and polyamine supplement, 9 kinds of SFM were designed by the response surface method. Cell cultures were performed with IL-2 supplementation, as described in the Materials and Methods section.

Figure 3A shows various combinations of cholesterol and polyamine supplement with a range of 0 and $4 x$ in these SFM. Excessively high concentrations of cholesterol and polyamine supplement did not promote cell growth in the preliminary cultivation (data not shown). PBMCs from the three different donors were cultivated

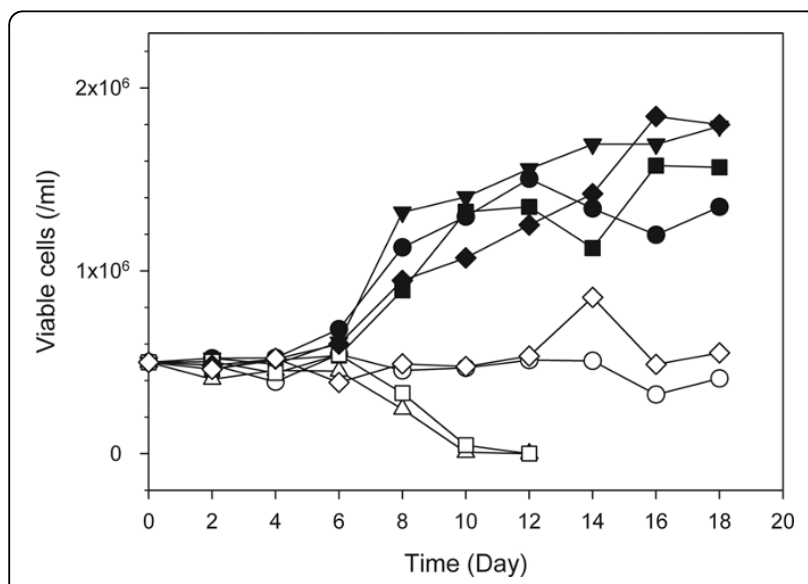

Figure 1 Growth profiles of cells cultured in 8 different SFM defined by the fractional factorial design. Cell cultures were replicated independently with PBMCs prepared from three different donors. This figure shows one representative growth profile among the three cultures. Black circles, SFM \#1; white circles, SFM \#2; inverted black triangles, SFM \#3; white triangles, SFM \#4; black squares, SFM \#5; white squares, SFM \#6; black diamonds, SFM \#7; white diamonds, SFM \#8. The compositions of the supplements for the eight media are shown in Table 2.
Table 3 Maximum viable cell concentrations in 8 SFM designed by the fractional factorial method

\begin{tabular}{crrr}
\hline SFM & \multicolumn{3}{c}{ Maximum viable cell concentration $(\mathbf{1 0}$ cells $/ \mathbf{m l})$} \\
\cline { 2 - 4 } & Set \#1 & Set \#2 & Set \#3 \\
\hline SFM \#1 & 15.03 & 25.38 & 39.60 \\
SFM \#2 & 5.12 & 7.83 & 7.95 \\
SFM \#3 & 17.91 & 24.84 & 49.32 \\
SFM \#4 & 4.56 & 4.62 & 7.02 \\
SFM \#5 & 15.75 & 28.80 & 37.80 \\
SFM \#6 & 5.42 & 4.72 & 6.52 \\
SFM \#7 & 18.45 & 19.44 & 42.66 \\
SFM \#8 & 8.55 & 6.03 & 4.89 \\
\hline
\end{tabular}

PBMCs were obtained from three different donors (Set \#1, Set \#2, and Set \#3). The seeding density was $5 \times 10^{5}$ cells $/ \mathrm{ml}$.

independently in these media for approximately three weeks. As summarized in Table 4, the highest maximum viable cell concentration was always achieved in

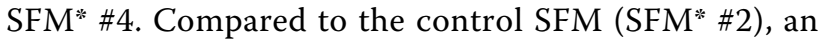
approximate 1.4 -fold increase in maximum viable cell concentration was achieved in $\mathrm{SFM}^{*}$ \#4. The results of the analysis of the response surface design using DesignExpert ${ }^{\circ}$ led to the optimized composition of SFM shown in Figure 3B. Thus, the preferred SFM formulation is the basal SFM supplemented with $3.3 \times$ of cholesterol $(13.2$ $\mathrm{mg} / \mathrm{l}$ ) and $0.1 \times$ of polyamine supplement (Sigma, \#P8483).

To confirm cell growth in the optimized SFM, PBMCs were cultivated with IL-2 supplementation in 10 kinds of SFM, including the optimized SFM and the 9 designed SFM shown in Figure 3A.

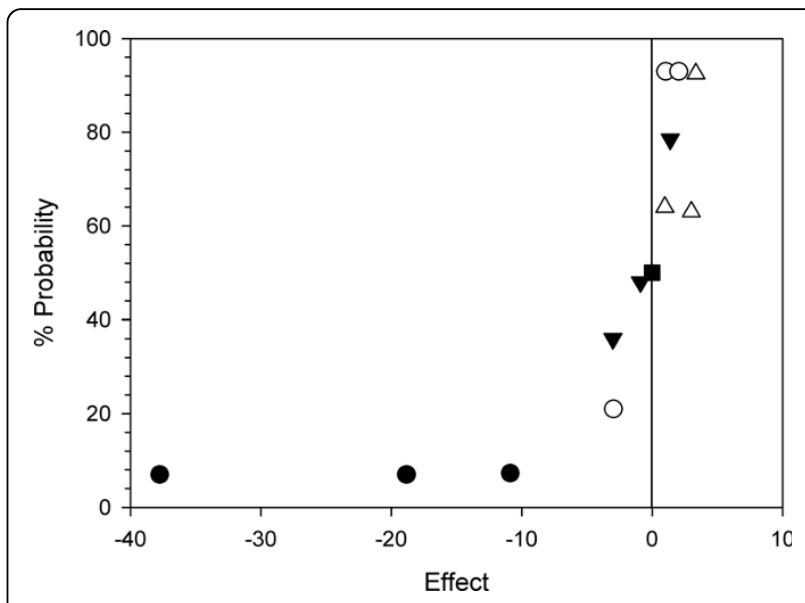

Figure 2 Normal probability plot of the effects obtained from 4 supplements. Black circles, phosphatidylcholine; white circles, polyamine supplement; inverted black triangles, antioxidant supplement; white triangles, cholesterol. The data points were plotted using maximum viable cell concentrations of three independent cultures. 


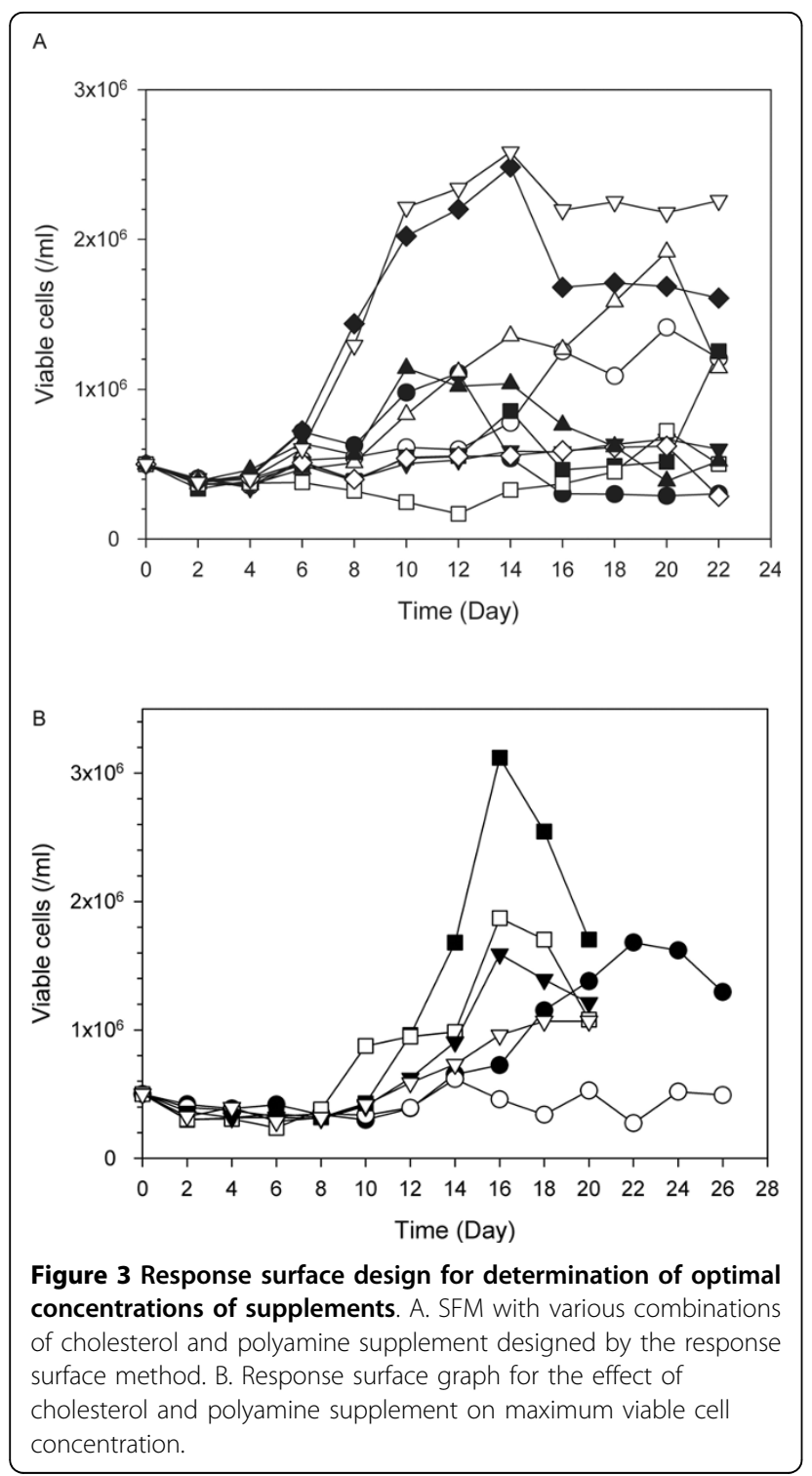

Figure 4A shows typical cell growth profiles of PBMCs in SFM. Cell growth in the optimized SFM was compared with the other SFM designed by the response surface method. In all three independent cultures of PBMCs isolated from the three different donors, cell growth in the optimized SFM was always better than that in any other medium. Growth performance in the optimized SFM was also compared with that in SCM. As shown in Figure 4B, growth performance of PBMCs in the optimized SFM depended on the donor. However, cell growth in the optimized SFM was always better than that in SCM.

Phenotypical analysis of cells cultured in developed SFM PBMCs comprise monocytes and lymphocytes including $\mathrm{T}$ cells $\left(\mathrm{CD}^{+}\right.$and $\left.\mathrm{CD}^{+}\right), \mathrm{B}$ cells, and NK cells. To
Table 4 Maximum viable cell concentrations in 9 SFM designed by the response surface method

\begin{tabular}{|c|c|c|c|}
\hline \multirow[t]{2}{*}{ SFM } & \multicolumn{3}{|c|}{ Maximum viable cell concentration $\left(10^{5}\right.$ cells $\left./ \mathrm{ml}\right)$} \\
\hline & Set \#1 & Set \#2 & Set \#3 \\
\hline SFM $^{*} \# 1$ & 18.12 & 16.47 & 9.66 \\
\hline $\mathrm{SFM}^{*} \# 2$ & 14.49 & 20.97 & 12.87 \\
\hline $\mathrm{SFM}^{*} \# 3$ & 22.68 & 9.45 & 13.38 \\
\hline $\mathrm{SFM}^{*} \# 4$ & 23.13 & 23.67 & 17.64 \\
\hline $\mathrm{SFM}^{*} \# 5$ & 9.01 & 9.48 & 8.61 \\
\hline $\mathrm{SFM}^{*} \# 6$ & 10.83 & 12.48 & 5.21 \\
\hline $\mathrm{SFM}^{*} \# 7$ & 15.21 & 21.24 & 16.20 \\
\hline $\mathrm{SFM}^{*} \# 8$ & 9.39 & 6.78 & 9.04 \\
\hline $\mathrm{SFM}^{*} \# 9$ & 12.78 & 13.20 & 7.11 \\
\hline
\end{tabular}

Concentrations of cholesterol and polyamine supplement in each SFM are shown in Figure 3A. Three sets of cultures were performed independently with PBMCs obtained from the three different donors. The seeding density was $5 \times 10^{5}$ cells $/ \mathrm{ml}$.

determine the possible changes in cell population of PBMCs cultured in the developed SFM with IL-2 supplementation, subsets of the population at the maximum viable cell concentration in SFM as well as SCM, as shown in Figure 4B, were analyzed by flow cytometry with fluorochrome-conjugated monoclonal antibodies (CD14 to monocytes, CD3 to $\mathrm{CD}^{+}$and $\mathrm{CD} 8^{+} \mathrm{T}$ cells, CD8 to $\mathrm{CD}^{+} \mathrm{T}$ cells, and CD19 to B cells).

Initially, the major cell population was $\mathrm{T}$ lymphocytes, while $13-27 \%$ of PBMCs were monocytes and B cells. Regardless of the culture media, most of the viable cells, after cultivation with IL-2 supplementation, were T lymphocytes, while monocytes and B lymphocytes were not detected. The percentage of $\mathrm{CD}^{+} \mathrm{T}$ lymphocyte population was similar between SFM and SCM $(p=0.22, \mathrm{n}=3)$. The results of the phenotypical analysis are summarized in Table 5.

\section{Functional assays of cells cultured in developed SFM}

To determine the effector function of CTLs cultivated in the developed SFM, antigen-specific CTLs were first generated from PBMCs, cultured in both the developed SFM and SCM, by stimulation of peptide-presenting DCs. The effector function of CTLs was then characterized by a cytotoxicity assay and an ELISpot assay. Functional assays were duplicated independently.

Figure $5 \mathrm{~A}$ shows the $\%$ cytotoxicity of antigen-specific CTLs. When $1 \times 10^{5}$ cells $/ \mathrm{ml}$ of target cells were cultivated with effector cells at a ratio of $1: 20$, the \% cytotoxicity of antigen-specific CTLs generated from PBMCs that had been cultured in the developed SFM, reached approximately $90 \%$; with dilution of these ratios to $1: 10$, $1: 5$, and $1: 2.5$, the \% cytotoxicity decreased to $69 \%, 35 \%$, and $12 \%$, respectively. Considering the standard deviations generated between replicated wells, the cytotoxicity of the cells cultured in the two media, SFM and SCM, 


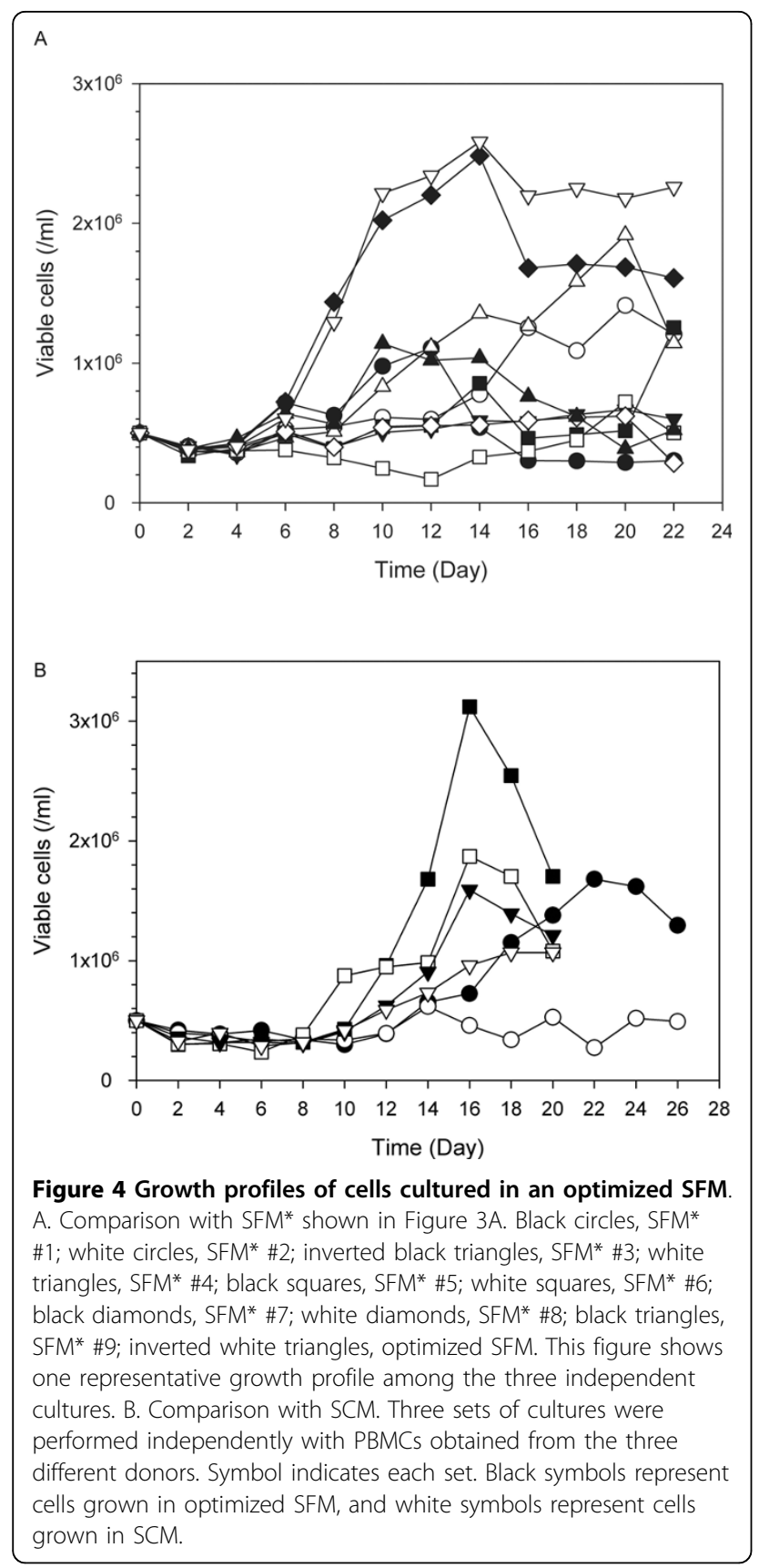

was approxymately the same $(p=0.47, p=0.97, p=0.27$, and $p=0.74$ at each ratio).

Figure 5B shows the results of the ELISpot assay. Unlike the cytotoxicity assay, the results of the ELISpot assay differed to a certain degree according to the medium in which the PBMCs were grown. In the case of PBMCs cultured in the developed SFM, an average of 67 spot-forming cells (SFC) $/ 10^{4}$ effector cells were observed after subtracting background spots, whereas in the case of PBMCs cultured in the SCM, an average of 17 $\mathrm{SFC} / 10^{4}$ effector cells were shown. SFC in SCM
Table 5 Phenotypical analysis of cells cultured in developed SFM and SCM

\begin{tabular}{rrrr}
\hline Set \#1 & PBMCs (\%) & SFM (\%) & SCM (\%) \\
\hline CD14 & 5.21 & - & - \\
CD19 & 20.63 & - & - \\
CD3 & 58.80 & 81.34 & 83.72 \\
CD8 & 20.42 & 30.50 & 29.86 \\
\hline Set \#2 & PBMCs (\%) & SFM (\%) & SCM (\%) \\
\hline CD14 & 6.66 & - & - \\
CD19 & 19.97 & - & - \\
CD3 & 62.99 & 84.32 & 88.83 \\
CD8 & 19.56 & 18.6 & 11.23 \\
\hline Set \#3 & PBMCs (\%) & SFM (\%) & SCM (\%) \\
\hline CD14 & 1.55 & - & - \\
CD19 & 11.53 & - & - \\
CD3 & 64.58 & 78.34 & 90.82 \\
CD8 & 19.32 & 28.58 & 6.80 \\
\hline
\end{tabular}

${ }^{a}$ Freshly thawed PBMCs, before cultivation, were analyzed.

${ }^{\mathrm{b}}$ Cell samples in the three independent cultures were taken at a maximum viable cell concentration (refer to Figure $4 \mathrm{~B}$ ).

c not detected.

decreased to one-fourth of that seen in SFM $(p<$ 0.001). According to a previous study [19], use of SFM should enhance (2.4-fold median increase) detection sensitivity in the ELISpot assay, which corresponds to the results of this study. Taken together, the use of developed SFM to culture PBMCs was advantageous, considering the cellular function as well as growth profiles.

\section{Discussion}

In developing SFM for in vitro expansion of human CTLs, a limitation of cell number from the same donor thwarted the employment of a full factorial design. In this study, a simple approach to screen media supplements that enhance the growth of $\mathrm{T}$ lymphocytes was described. The approach combined elements of statistical experimental design with maximum cell concentration to identify potent growth responses of $\mathrm{T}$ lymphocytes. The use of normal probability plots confirmed the experimental results in a statistical sense which provided a simple means of analyzing and prioritizing the consequences of our experimental results.

Although serum has previously been replaced by several supplements in lymphocyte cultures [8], the SFM developed in this study showed a more enhanced effect on the growth of lymphocytes. We adopted a basal SFM with the serum-free components listed in Table 1. Transferrin, a widely used but expensive growth factor, was also successfully replaced by ferric citrate which could deliver iron to cells. In addition, 2-mercaptoethanol and 1-thioglycerol were used because they were reported as positive factors on proliferation and activation of lymphocytes [9]. 


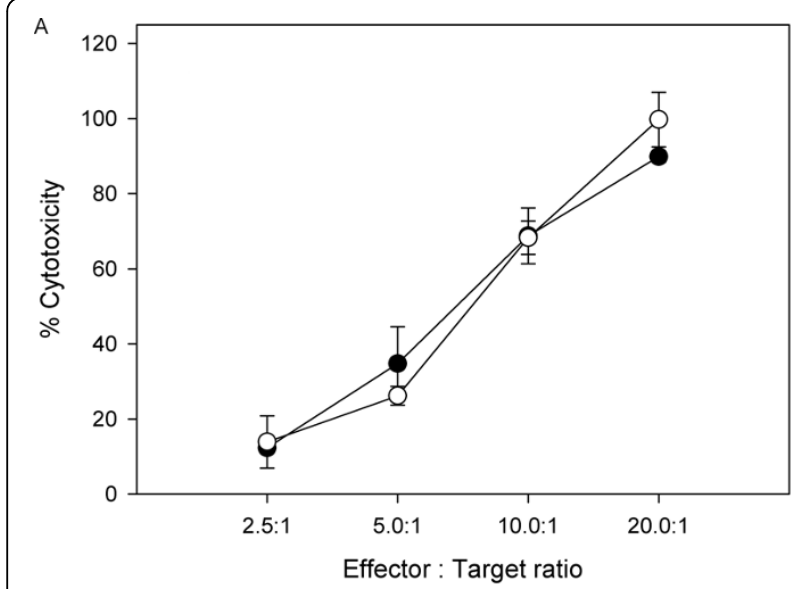

B

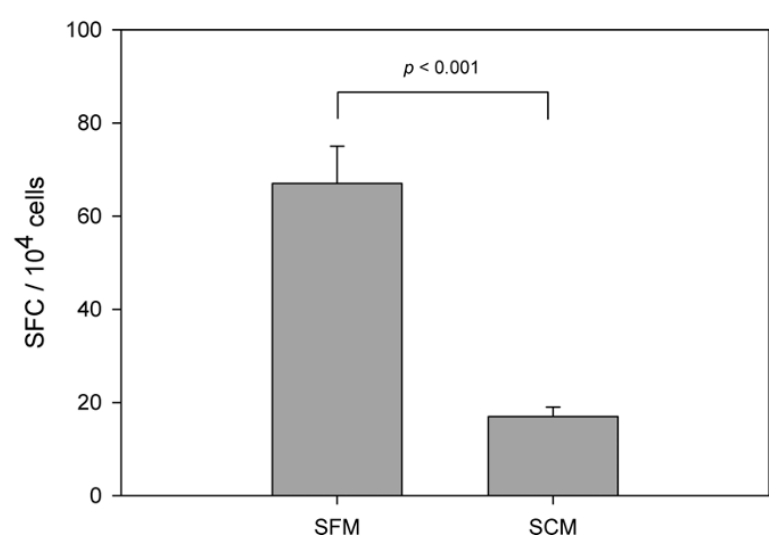

Figure 5 Functional assays of CMV-specific CTLs generated from PBMCs cultured in the developed SFM and SCM. A.

Cytotoxicity of CMV-specific CTLS generated from PBMCs cultured in the developed SFM (black circles) and SCM (white circles) was tested for their ability to lyse target cells. B. CMV-specific responses obtained by ELISpot using the developed SFM and SCM as culture media. Functional assays were duplicated independently and each experiment was carried out in triplicates. Error bar represents the standard deviation $(n=3)$.

Among four candidates chosen to further enhance the growth of lymphocytes, cholesterol and polyamine supplement were selected as active factors on cell growth by analysis of Design-Expert ${ }^{\circ}$. Cholesterol, one of the major lipid constituents in serum, is a major lipid component of the plasma membrane in most cells, and polyamines including putrescine and spermidine are commonly used to supplement SFM for a variety of cell types [20-22]. The optimal concentrations of these two supplements were $3.3 \times$ of cholesterol and $0.1 \times$ of polyamine supplement. The optimal concentration of polyamine supplement was quite low, compared to that of cholesterol. In three independent cultures, cholesterol always showed a positive effect on cell growth. However, in the case of polyamine supplement, a negative effect on growth was observed in one case. Polyamine supplement, similar to antioxidant supplement, which showed inconsistent responses in repeated experiments, displayed a marginal effect on cell growth.

On the other hand, although being universally used in SFM as a lipid source, phosphatidylcholine showed a significantly negative effect on the growth of lymphocytes. Phosphatidylcholine is one of the phospholipids that constitute serum, and it is known as an active factor on cell growth $[12,23]$. The effect of phosphatidylcholine, however, could be affected by the kinds of cells cultured and the concentration of phosphatidylcholine used $[24,25]$. In addition, the effects of phosphatidylcholine on cell growth were influenced by the lipids present in serum [26]. Therefore, it is assumed that lymphocyte culture can be negatively affected by phosphatidylcholine, especially when fatty acids are supplemented as a lipid replacement.

For the rapid generation of large numbers of CTLs, different strategies have been employed, each having respective, and debatable, pros and cons. In some cases, $\mathrm{CD}^{+} \mathrm{T}$ cells are initially separated from PBMCs, and the process of expansion is then completed [27]. Such a strategy would yield a greater number of CTLs at the end of the culture. However, in this study, since the focus was on developing a SFM, culture strategy was not emphasized.

As expected, growth profiles of PBMCs, which are not a continuous cell line, varied depending on the donors. In some cases, when cells were cultured in SCM, they did not grow (Figure 4B). Furthermore, with regard to the $\%$ of $\mathrm{CD}^{+}$lymphocytes in the cultured cells, variation between donors in SCM was more significant than that in SFM (Table 5). Therefore, use of SFM can reduce the variation that can be generated from many causes during the culture period. Furthermore, cytotoxicity and ELISpot assays revealed that the effector function of CTLs cultivated in the developed SFM was retained or even better than that in SCM.

\section{Conclusions}

SFM with cholesterol and polyamine supplement for human lymphocyte culture was developed efficiently using a statistical method. This SFM provides better or at least equivalent performance with respect to cell growth, variation in cell population, and cytotoxicity, compared to SCM.

\section{Methods}

\section{Medium composition and preparation}

A basal SFM, which was developed in our laboratory, was based on RPMI1640 medium (Invitrogen, Grand Island, NY) containing $2 \mathrm{~g} / \mathrm{l} \mathrm{NaHCO}_{3}$ (Sigma, St. Louis, MO). All supplements used in the basal SFM, unless otherwise specified, were purchased from Sigma and 
their concentrations are given in Table 1 . Insulin and ferric citrate were prepared in $1 \mathrm{M}$ acetic acid and boiling water, respectively. Fatty acids such as linoleic acid, oleic acid, and palmitic acid were first dissolved in ethanol and then diluted in culture medium. RPMI1640 non-essential amino acids (Sigma, \#R7131) and vitamins solution (Sigma, \#R7256) were added as $1 \times$ concentration in culture medium before use. Other supplements were dissolved in water before addition to the culture medium.

Fetal bovine serum (FBS) used in serum-containing medium (SCM) was purchased from Invitrogen, and a commercial SFM, X-VIVO15, was purchased from Lonza (Walkersville, MD). Interleukin-2 (IL-2) (Millipore, Bedford, MA), which was added into the culture media as a growth factor, was reconstituted in $100 \mathrm{mM}$ acetic acid.

\section{Potential components for growth enhancement}

Four supplements were chosen according to their general function in cell culture. The supplements were (1) phosphatidylcholine ( $5 \mathrm{mg} / \mathrm{l})$, (2) polyamine supplement (\#P8483), (3) antioxidant supplement (\#A1345), and (4) cholesterol (4 mg/l) (all from Sigma). Polyamine supplement and antioxidant supplement were supplied as $1000 \times$ concentrates. Phosphatidylcholine and cholesterol were first dissolved in ethanol and then diluted in the culture medium before use.

\section{Experimental design and statistical analysis}

An experimental design was applied using DesignExpert $^{\circ}$ software (version 7.1.2, Stat-Ease, Inc., MN) employing one-half fraction of the two-level factorial design with 4 factors $\left(2^{4-1}\right)$ involving 8 combinations of all factors (Table 2). The 4 supplements were screened using two-level fractional factorial designs to estimate their effect on maximum cell concentration. After selecting two positive determinants on growth, 9 kinds of SFM were determined by response surface designs with range of these supplement concentrations between 0 and $4 \times$. Design-Expert ${ }^{\circ}$ provided a fractional factorial matrix, a normal probability plot, a response surface matrix, and a contour plot of the predicted elongation values of maximum cell concentration. It was then possible to find the optimal concentrations of two positive supplements for cell growth. The response surface designs were analyzed by fitting a quadratic model. The model adequacy was confirmed using analysis of variance (ANOVA).

\section{In vitro lymphocyte culture}

Peripheral blood mononuclear cells (PBMCs) were collected by apheresis from normal HLA-A0201 donors after obtaining informed consent. PBMCs were isolated from the apheresis product by Ficoll-Hypaque density gradient centrifugation (Pharmacia Biotech, Wikstrom, Sweden) and cryopreserved at $-160^{\circ} \mathrm{C}$ in human $\mathrm{AB}^{+}$ serum and RPMI1640 medium (Invitrogen) containing 10\% DMSO (Sigma), as described previously [28].

After thawing, isolated PBMCs were washed twice with phosphate-buffered saline (PBS) before seeding. PBMCs $\left(5 \times 10^{5}\right.$ cells $\left./ \mathrm{ml}\right)$ were plated into 24 -well plates (Nunc, Roskilde, Denmark) containing $2 \mathrm{ml}$ of culture media and then cultivated in a $5 \% \mathrm{CO}_{2}$ /air mixture, humidified at $37^{\circ} \mathrm{C}$. Every two days, $1 \mathrm{ml}$ of culture supernatant was gently replaced with $1 \mathrm{ml}$ of the fresh medium supplemented with IL-2 (Millipore). The final IL-2 concentration in culture media was $50 \mathrm{U} / \mathrm{ml}$. For determination of viable cell concentration, each well was sacrificed every other day. Viable cell concentration was estimated by the trypan blue dye exclusion method using a hemacytometer. Unless specified, all cell cultures were performed three times with PBMCs isolated from different donors.

\section{Generation of CMV-specific CTLs}

To generate CMV-specific CTLs for functional assays, peptide-loaded autologous dendritic cells (DCs) were first generated as previously described $[4,28]$. Briefly, PBMCs were incubated for $2 \mathrm{~h}$ at $37^{\circ} \mathrm{C}$ in X-VIVO15 medium. Adherent monocytes were suspended at a concentration of $1 \times 10^{6}$ cells $/ \mathrm{ml}$ in X-VIVO15 supplemented with GM-CSF (800 U/ml, Millipore) and interleukin-4 (IL- 4, $1000 \mathrm{U} / \mathrm{ml}$, Millipore). On day 2 and 4 of culture, spent medium was exchanged with fresh medium containing $1600 \mathrm{U} / \mathrm{ml}$ of GM-CSF and $1000 \mathrm{U} / \mathrm{ml}$ of IL-4. On day $5,200 \mathrm{U} / \mathrm{ml}$ of tumor necrosis factor- $\alpha$ (TNF- $\alpha$ ) (Millipore) was added for the maturation of DCs. After 48 $h$ maturation, autologous DCs were pulsed with NLVPMVATV peptides (10 $\mu \mathrm{g} / \mathrm{ml}$, Peptron, Korea), HLAA0201 restricted CMV peptide epitope, for at least $2 \mathrm{~h}$ and then irradiated (25 Gy).

PBMCs cultured in vitro using culture media supplemented with IL-2 (developed SFM or serum-containing medium (SCM): RPMI1640 supplemented with $10 \%$ FBS) were plated at a concentration of $1 \times 10^{6}$ cells/well in a 24-well culture plate (Nunc) with $2 \mathrm{ml}$ of the corresponding culture media and directly stimulated with peptides at a concentration of $10 \mu \mathrm{g} / \mathrm{ml}$ (day 0 ) and with peptide-pulsed of autologous DCs (at a ratio of 1:10 DCs to PBMCs, day 7, day 14 and day 21 for a 4week expansion). Every two days, $1 \mathrm{ml}$ of culture supernatant was gently replaced with $1 \mathrm{ml}$ of the fresh medium supplemented with IL-2 (50 U/ml, Millipore). After 24 days of cultivation, cells were subjected to cytotoxicity and ELISpot assays.

\section{Flow cytometry}

Fresh PBMCs isolated by Ficoll-Hypaque density gradient centrifugation and 15-day cultured PBMCs were 
prepared for flow cytometric phenotypic analysis. Flow cytometry was performed according to standard procedures. In brief, $5 \times 10^{5}$ cells/tube were stained in the dark for $20 \mathrm{~min}$ at $4^{\circ} \mathrm{C}$ with FITC-labeled anti-CD3, PElabeled anti-CD8, FITC-labeled anti-CD19 or PE-labeled anti-CD14 monoclonal antibody. All antibodies were obtained from BD Biosciences (San Diego, CA). Unstained cells were used as a negative control. After washing in PBS, cells were analyzed on a FACS LSRII (BD Biosciences) using Flowjo software (Tristar, San Carlos, CA)

\section{Cytotoxicity}

The cytotoxic specificity was determined by lysis of target cells using a lactate dehydrogenase (LDH)-release assay (CytoTox $96^{\circ}$ non-radioactive cytotoxicity assay kit, Promega, Madison, WI) according to the manufacturer's instructions. Peptide-sensitized PBMCs were used as effector cells and peptide-presenting autologous DCs were used as target cells. Each test was repeated twice in two media (SFM and SCM). Target cells $(1 \times$ $10^{5}$ cells $/ \mathrm{ml}$ ) were cultured with effector cells at various ratios of target cells to effector cells (1:20, 1:10, 1:5, and $1: 2.5$ ) in 96-well U-bottom plates (Nunc) in $100 \mu \mathrm{l}$ of culture media for $6 \mathrm{~h}$. Cells were plated in triplicates at each ratio. LDH release was quantified by measuring wavelength absorbance at $490 \mathrm{~nm}$. The percentage of target cell lysis was calculated according to the following formula: [(experimental LDH release - target cells spontaneous LDH release - effector cells spontaneous LDH release $) \times 100] /[($ target maximum $\mathrm{LDH}$ release - target spontaneous LDH release)].

\section{ELISpot assay}

To determine the frequency of $\mathrm{T}$ lymphocytes capable of responding to a specific stimulus by secretion of IFN$\gamma$, an ELISpot assay was carried out as described previously [29-31]. Polyvinylidene fluoride (PVDF) plates (Millipore) were coated with anti-IFN- $\gamma$ monoclonal antibody (BD Biosciences) $(10 \mu \mathrm{g} / \mathrm{ml}$ in PBS) and incubated overnight at $4^{\circ} \mathrm{C}$. Plates were then washed 6 times with PBS to remove unbound antibody. After blocking with culture media (SFM or SCM) at room temperature for $1 \mathrm{~h}$, peptide-sensitized PBMCs $\left(1 \times 10^{4} /\right.$ well $)$ were plated in triplicates with peptide-presenting autologous DCs $\left(1 \times 10^{3} /\right.$ well in $100 \mu \mathrm{l}$ of culture media. Cells cultured without activation with DCs were used as a control. After incubation at $37^{\circ} \mathrm{C}, 5 \% \mathrm{CO}_{2}$ humidified incubator for $24 \mathrm{~h}$, cells were removed from the plates by 5 washes with PBS and one wash with distilled water. $\mathrm{PBS} / \mathrm{T}$ was then used for all further washing steps. Wells were incubated with $100 \mu \mathrm{l}$ of biotinylated monoclonal anti-human IFN $-\gamma$ antibody $(1 \mu \mathrm{g} / \mathrm{ml}$ PBS/FBS $10 \%$, BD Biosciences) for $2 \mathrm{~h}$ at $37^{\circ} \mathrm{C}, 5 \% \mathrm{CO}_{2}$, to detect captured IFN- $\gamma$. After 6 washes, $100 \mu \mathrm{l}$ of avidin-horseradish peroxidase conjugate (1:1000 dilution in PBS/FBS $10 \%$, BD Biosciences) was added. After $1 \mathrm{~h}$ incubation at room temperature, wells were washed six times. Coloration was developed with 3-Amino-9-ethylcarbazole (AEC, Sigma) and the reaction was terminated after 20 min by washing the plates with distilled water. The visible spots were counted using a Stemi 2000-C dissecting microscope (Carl Zeiss, Inc., Thornwood, NJ).

\section{Acknowledgements}

This research was supported in part by WCU program through the KOSEF funded by the MEST (grant number: R31-2008-000-10071-0) and the Ministry of Commerce, Industry, and Energy. We thank KAIST Language Center for the copy-editing service.

\section{Author details}

${ }^{1}$ Department of Biological Sciences and Graduate School of Nanoscience \& Technology (WCU), KAIST, 335 Gwahangno, Yuseong-gu, Daejon, 305-701, Korea. ${ }^{2}$ Department of Laboratory Medicine, Yonsei University College of Medicine, Seoul, Korea.

\section{Authors' contributions}

$M K J, J B L$, and GML designed the research. MKJ performed all the experiments and analyzed the data. JBL supported by supplying PBMCs. JBL and GML conceived the study. MKJ and GML wrote the manuscript. All authors have read and approved the final manuscript.

Received: 8 December 2009 Accepted: 21 September 2010 Published: 21 September 2010

\section{References}

1. Lim JB, Kwon OH, Kim HS, Kim HO, Choi JR, Provenzano M, Stroncek D: Adoptive immunotherapy for cytomegalovirus (CMV) disease in immunocompromised patients. Yonsei Med J 2004, 45(Suppl):18-22.

2. Powell DJ Jr, Levine BL: Adoptive T-cell therapy for malignant disorders. Haematologica 2008, 93:1452-1456.

3. van Rhee F, Barrett J: Adoptive transfer of Ag-specific T cells to prevent CMV disease after allogeneic stem-cell transplantation. Cytotherapy 2002, 4:3-10.

4. Foster AE, Gottlieb DJ, Marangolo M, Bartlett A, Li YC, Barton GW, Romagnoli JA, Bradstock KF: Rapid, large-scale generation of highly pure cytomegalovirus-specific cytotoxic T cells for adoptive immunotherapy. J Hematother Stem Cell Res 2003, 12:93-105.

5. Walter EA, Greenberg PD, Gilbert MJ, Finch RJ, Watanabe KS, Thomas ED, Riddell SR: Reconstitution of cellular immunity against cytomegalovirus in recipients of allogeneic bone marrow by transfer of T-cell clones from the donor. N Engl J Med 1995, 333:1038-1044.

6. Cooper LJ, Ausubel L, Gutierrez M, Stephan S, Shakeley R, Olivares S, Serrano LM, Burton L, Jensen MC, Forman SJ, DiGiusto DL: Manufacturing of gene-modified cytotoxic T lymphocytes for autologous cellular therapy for lymphoma. Cytotherapy 2006, 8:105-117.

7. Foster AE, Forrester K, Gottlieb DJ, Barton GW, Romagnoli JA, Bradstock KF: Large-scale expansion of cytomegalovirus-specific cytotoxic T cells in suspension culture. Biotechnol Bioeng 2004, 85:138-146.

8. Yssel H, De Vries JE, Koken M, Van Blitterswijk W, Spits H: Serum-free medium for generation and propagation of functional human cytotoxic and helper T cell clones. J Immunol Methods 1984, 72:219-227.

9. Goodman MG, Weigle WO: Nonspecific activation of murine lymphocytes. I. Proliferation and polyclonal activation induced by 2-mercaptoethanol and alpha-thioglycerol. J Exp Med 1977, 145:473-489.

10. Polet $H$, Spieker-Polet $H$ : Serum albumin is essential for in vitro growth of activated human lymphocytes. J Exp Med 1975, 142:949-959.

11. Bottenstein JE, Sato GH: Growth of a rat neuroblastoma cell line in serum-free supplemented medium. Proc Natl Acad Sci USA 1979, 76:514-517. 
12. Fujii DK, Cheng J, Gospodarowicz D: Phosphatidyl choline and the growth in serum-free medium of vascular endothelial and smooth muscle cells, and corneal endothelial cells. J Cell Physiol 1983, 114:267-278.

13. Haeffner EW, Hoffmann CJ, Stoehr M, Scherf H: Cholesterol-induced growth stimulation, cell aggregation, and membrane properties of ascites tumor cells in culture. Cancer Res 1984, 44:2668-2676.

14. Sandadi S, Ensari S, Kearns B: Application of fractional factorial designs to screen active factors for antibody production by chinese hamster ovary cells. Biotechnol Prog 2006, 22:595-600.

15. McLaughlin-Taylor E, Pande H, Forman SJ, Tanamachi B, Li CR, Zaia JA, Greenberg PD, Riddell SR: Identification of the major late human cytomegalovirus matrix protein pp65 as a target antigen for CD8+ virusspecific cytotoxic T lymphocytes. J Med Virol 1994, 43:103-110.

16. Solache A, Morgan CL, Dodi Al, Morte C, Scott I, Baboonian C, Zal B, Goldman J, Grundy JE, Madrigal JA: Identification of three HLA-A*0201restricted cytotoxic T cell epitopes in the cytomegalovirus protein pp65 that are conserved between eight strains of the virus. J Immunol 1999, 163:5512-5518.

17. Wills MR, Carmichael AJ, Mynard K, Jin X, Weekes MP, Plachter B, Sissons JG: The human cytotoxic T-lymphocyte (CTL) response to cytomegalovirus is dominated by structural protein pp65: frequency, specificity, and T-cell receptor usage of pp65-specific CTL. J Virol 1996, 70:7569-7579.

18. Stamatis DH: Six sigma and beyond: Design of experiments Boca Raton, FL: St. Lucie Press 2001.

19. Martinuzzi E, Scotto M, Enee E, Brezar V, Ribeil JA, van Endert P, Mallone R: Serum-free culture medium and IL-7 costimulation increase the sensitivity of ELISpot detection. J Immunol Methods 2008, 333:61-70.

20. Xu F, Rychnovsky SD, Belani JD, Hobbs HH, Cohen JC, Rawson RB: Dual roles for cholesterol in mammalian cells. P Natl Acad Sci USA 2005, 102:14551-14556.

21. Albrecht I, Gatfield J, Mini T, Jeno P, Pieters J: Essential role for cholesterol in the delivery of exogenous antigens to the MHC class I-presentation pathway. Int Immunol 2006, 18:755-765.

22. Sandstrom CE, Miller WM, Papoutsakis ET: Serum-free media for cultures of primitive and mature hematopoietic cells. Biotechnol Bioeng 1994, 43:706-733.

23. Cuadrado A, Carnero A, Dolfi F, Jimenez B, Lacal JC: Phosphorylcholine: a novel second messenger essential for mitogenic activity of growth factors. Oncogene 1993, 8:2959-2968.

24. Caselli E, Baricordi OR, Melchiorri L, Bellini F, Ponzin D, Bruni A: Inhibition of DNA synthesis in peripheral blood mononuclear cells treated with phosphatidylserines containing unsaturated acyl chains. Immunopharmacology 1992, 23:205-213.

25. Kremlev SG, Umstead TM, Phelps DS: Effects of surfactant protein A and surfactant lipids on lymphocyte proliferation in vitro. Am J Physiol 1994, 267:L357-364.

26. Nishiyama-Naruke A, Curi R: Phosphatidylcholine participates in the interaction between macrophages and lymphocytes. Am J Physiol Cell Physiol 2000, 278:C554-560.

27. Al-Shanti N, Aldahoudi Z: Human purified CD8+ T cells: Ex vivo expansion model to generate a maximum yield of functional cytotoxic cells. Immunol Invest 2007, 36:85-104.

28. Lim JB, Provenzano M, Kwon OH, Bettinotti M, Caruccio L, Nagorsen D, Stroncek D: Identification of HLA-A33-restricted CMV pp65 epitopes as common targets for CD8(+) CMV-specific cytotoxic T lymphocytes. Exp Hematol 2006, 34:296-307.

29. Herr W, Schneider J, Lohse AW, Meyer zum Buschenfelde KH, Wolfel T: Detection and quantification of blood-derived CD8+ T lymphocytes secreting tumor necrosis factor alpha in response to HLA-A2.1-binding melanoma and viral peptide antigens. J Immunol Methods 1996, 191:131-142.

30. Kleihauer A, Grigoleit U, Hebart H, Moris A, Brossart P, Muhm A, Stevanovic S, Rammensee HG, Sinzger C, Riegler S, Jahn G, Kanz L, Einsele $H$ : Ex vivo generation of human cytomegalovirus-specific cytotoxic T cells by peptide-pulsed dendritic cells. Br J Haematol 2001, 113:231-239

31. Metes D, Storkus W, Zeevi A, Patterson K, Logar A, Rowe D, Nalesnik MA, Fung JJ, Rao AS: Ex vivo generation of effective Epstein-Barr virus (EBV)specific CD8+ cytotoxic T lymphocytes from the peripheral blood of immunocompetent Epstein Barr virus-seronegative individuals. Transplantation 2000, 70:1507-1515. doi:10.1186/1472-6750-10-70

Cite this article as: Jeon et al.: Development of a serum-free medium

for in vitro expansion of human cytotoxic T lymphocytes using a statistical design. BMC Biotechnology 2010 10:70.

\section{Submit your next manuscript to BioMed Central and take full advantage of:}

- Convenient online submission

- Thorough peer review

- No space constraints or color figure charges

- Immediate publication on acceptance

- Inclusion in PubMed, CAS, Scopus and Google Scholar

- Research which is freely available for redistribution 